\title{
Introduction: Gender in the Global South: Disturbing International Boundaries
}

\section{Natália Maria Félix de Souza*}

Emerging from an urgent sense of the importance of dislocating universalist narratives about the international, this Special Issue of Contexto Internacional, titled Gender in the Global South: Disturbing International Boundaries, opens the discussion on the state of Gender, Sexuality and Women's Studies from a global South perspective. The collection of essays gathered in this first of three parts of the Special Issue offers intricate and complementary reflections on the ways bodies marked by gendered categories manage to exist, to move, to resist and to survive in spite of structures that try to pin them down, silence their voices, erase their existence. By means of narrative, conceptual, political and ethnological meditations, they show how these bodies insist to re-exist (Walsh 2013) despite the multifarious structures of power that render their lives both possible and impossible.

The 'Global South' to which these articles allude is not definable by any territorial coordinate or geographical constellation; rather, it criss-crosses the complex territorialities of the international, imbricates the very fabric of everyday lives, from media representations to the urban dynamics of an ordinary metropolis. For this reason, these contributions cannot be contained within any single narrative about women, feminism, or gender, but multiply the possibilities of extending our curiosity (Enloe 2004) to times and places in which categories of sex, gender, race, ethnicity and class intertwine to produce complex subjectivities. Departing from gendered categories, they paint a nuanced view of how power operates, and how it is - or can be - resisted and negotiated in different ways by people inhabiting multiple geographical, political, normative and affective spaces.

The recognition of the importance of situational and intersectional perspectives in feminist theorizing is not particularly new (Mohanty 1984; Crenshaw 1989; Haraway 1991; Butler 1993; Lugones 2010). Recent waves of theorization on gender have, however, become more cognizant of the differences that affect sexed bodies in multiple ways so as to produce alternative possibilities for thinking and acting politically. This transformation has been deeply tied to a more general problematization of the Eurocentric basis through

Pontifícia Universidade Católica de São Paulo (PUC-SP), São Paulo-SP, Brazil; nataliamfsouza@gmail.com. ORCID iD 0000-0001-9914-8985. 
which knowledge production has been pursued (Chakrabarty 2000; Mignolo 2000; Inayatullah and Blaney 2004; Jones 2006; Tickner and Blaney 2013), in a movement that led to the growing appreciation of the 'Global South' as a legitimate locus of enunciation. The impact of such a transformation of the usual loci of enunciation and knowledge production has been central for feminist, gender and queer studies, which have been trying to account for the ineradicable multiplicity of places, histories, bodies, and subjectivities.

In this sense, the reflections collected in this triple Special Issue offer more than an intellectual contribution to gender studies in general; they make a very timely political intervention, in particular when we consider the state of gender studies in Brazilian International Relations. The growing attention that issues of feminism, gender and sexuality has been gathering in this field since 2016 has led to the affirmation of a feminist turn in Brazilian International Relations (Galhera and Maso 2017) - a recognition of an emerging political and intellectual agenda, as well as of the need to carefully build researches and sensibilities that do not reproduce silences and invisibilities. The moment, therefore, requires paying attention to gendered bodies and experiences in their multiplicity and complexity, opening spaces in which their voices can be heard (Spivak 1988), rather than looking for a single grandiose intervention.

In this historical moment, it becomes paramount to retrieve the importance of Cynthia Enloe's work for feminist theorizing in international relations. Enloe's popularization of the idea that 'the personal is international; the international is personal' ([1990] 2014: 343) has contributed to the appreciation of the intricate workings of power in the reproduction of international political structures. By doing so, her research has been able to highlight different ways in which categories of gender, race, class, ethnicity intertwine to produce complex individual experiences and trajectories, debunking any simplistic view of the 'women' who make up the international. By doing so, Enloe has promoted a powerful dislocation of the boundaries of the international. This is why her work remains so central for the interventions summoned in this Special Issue.

The articles that follow offer contributions that engage one or more of the following questions:

- How is gender analysis impacted by the political and discursive affirmation of the divide between North/South; West/East; First World/Third World?

- How does gender analysis help to dislocate the political and epistemological boundaries of international relations?

- How do sex and gender binaries affect the production of subjectivities in the global South?

- How do alternative epistemological approaches to gender help to navigate the multiple experiences of people who inhabit - physically or intellectually - the global South?

- How do the multiple intersectionalities of sex, gender, race and class affect the lived experiences of people in the global South, and how do these experiences shape the workings of international politics in the $21^{\text {st }}$ century? 


\section{Organization of the issue}

In the first piece, titled 'What is she thinking', Natália Félix strikes up a conversation with Cynthia Enloe on the lasting legacy of her work to the field of international relations, as well as on the enduring barriers that Sexuality, Gender and Women's Studies continue to face in their attempt to challenge patriarchal structures sustaining not only the academic field, but the functioning of international politics more generally. In this productive encounter, Enloe reflects upon the historical importance of her intervention, offering some fresh provocations on the ways patriarchy continues to impact contemporary social and political structures - including the University. Furthermore, the author produces a complex picture of some of the particular challenges that feminism and feminists face when confronted by the lasting power structures of coloniality in the global South. In this regard, Enloe offers some inviting suggestions on the productivity and potentiality of encounters between feminists in the academia and the streets, showing the powerful symbiosis between research and activism for advancing feminist agendas all over the world.

The articles that follow this conversation pick up on many of these themes and produce some original visions on the networks of power and resistance sustaining gendered and racialized international political structures. In the article 'De-Securitising "the South in the North"? Gendered Narratives on the Refugee Flows in the European Mediascape, Rita Santos, Silvia Roque and Sofia José Santos highlight the joint contribution of critical and feminist security studies to show how British media representations of the refugee flows between 2015-2016 became central to produce an imaginary of crisis, legitimating the use of exceptional measures. The authors offer an insightful rendition of the ways in which gendered and racialized representations of refugee flows have rendered operative narratives, discourses and practices authorizing a civilized European (masculine) solution to intervene in a savage (feminine) global South. Whether depicting them as threatening criminals or passive victims, hegemonic media representations have denied refugees any complexity, leading to their dehumanization and objectification by rendering them voiceless and without agency.

Dislocating their sight to the contemporary Kurdish women's movement, Vinícius Santiago and Bruna Ferreira make a powerful claim concerning the ways in which women's agency has been central in shattering the pillars sustaining the Turkish nation-state - such as capitalism and patriarchy - and therefore, disturbing the boundaries of the international system. In the article 'The Core of Resistance: Recognizing Intersectional Struggle in the Kurdish Women's Movement,' the authors address the existence of multiple and intricate networks of power which produce women's subjection - from the organization of the national state, to the creation of the Kurdistan Workers' Party, to the relationship to their male comrades. By paying attention to the women's intersectional struggles based on gender, ethnicity and class, they are able to produce a complex image of how contemporary Kurdish women's organization in Rojava has been opening avenues for dif- 
ferent political communities - showing not only that 'the personal is political', but that the personal is central for rearticulating the political.

The last three articles engage issues of prostitution and sex trafficking, complicating any easy assumptions about voluntary versus exploitative/compulsory sex work. Together, they shed light into the myriad power relations that structure discourses and practices of prostitution, creating a critical opportunity for more nuanced debates about prostitution and the politics involving sexed bodies and subjectivities in often marginal(ized) places.

In the article 'Migration and Sex Work through a Gender Perspective,' Charlotte Valadier clears some important ground on the conceptualization of prostitution, migration and sex trafficking - terms that, more often than not, lead to some extreme incomprehension and confusion. The article offers a typological approach to the way different strands of feminism have variously treated the subject of sex work, refusing the dualistic 'sex war' between the abolitionist/radical and the liberal/legalising approaches, and exploring the existence of subtleties and nuances which pervade different experiences of sex work. Valadier's discussion of the contributions of a postmodern feminism to the debate over the global mobility of migrants working in the transnational sex industry is particularly relevant for contexts such as the Brazilian one, where sex work is part of complex networks of power that structure society - and yet remains a broadly silenced and concealed activity, rendering so many bodies and subjectivities invisible or inexistent, and therefore, abject.

Amanda Ferreira shares many of Valadier's sensibilities by offering an inviting opportunity to disturb the international boundaries sustaining the debate on prostitution. Equally critical of the 'abolitionist' versus 'legalising' approaches sustaining debates about prostitution in Brazil, the article 'Queering the Debate: Analysing Prostitution through Dissident Sexualities in Brazil' unmasks their underlying heteronormativity by looking at transgender prostitution in the country. Ferreira employs a Butlerian perspective to deconstruct normative binaries and show the impossibility of identity of travestis' experience and performances. The remarkable contribution of this article is to shed light into the ways travestis' bodies and their dissident sexualities, by embracing deviation, can pose a queer challenge to the heteronormative society of Brazil. Refusing any authoritative explanation of transgender prostitution, the article broadens the possibilities of intervention of a feminist project.

The last article by Thaddeus Blanchette and Ana Paula da Silva further deepens the complexity of the debate over prostitution by presenting a very intricate view of sex work based on 12 years of ethnographic research in Brazil. In 'Classy Whores: Putafeminismo, Sex, and Work in Brazil,' the authors highlight the importance of putafeminismo - to dismantle the pervasiveness of 'whorephobia' and defy the longstanding criminalization of sex workers in Brazilian society - something that traditional feminist approaches have so far failed to do. The authors' research shows in putafeminismo an intersectional feminist approach based on the lived experiences of class, citizenship, and race among women, one that combats the social stigma of the 'whore' and creates an opportunity to build social 
justice for their often abject bodies. By engaging sex work as a form of labour - i.e. one that creates domination and alienation, but that also presents opportunities for resistance by providing a common basis for sociopolitical mobilization - their argument brings visibility to prostitutes' struggles as a working-class struggle against capital and neoliberalism.

\section{References}

Butler, Judith. 1993. Bodies that Matter: On the Discursive Limits of Sex. London/New York: Routledge.

Chakrabarty, Dipesh. 2000. Provincializing Europe: Postcolonial Thought and Historical Difference. Princeton: Princeton University Press.

Crenshaw, Kimberle. 1989. 'Demarginalizing the Intersection of Race and Sex: A Black Feminist Critique of Antidiscrimination Doctrine, Feminist Theory and Antiracist Politics.' University of Chicago Legal Forum (1): 139-167.

Enloe, Cynthia. 2004. The Curious Feminist: searching for women in a new age of empire. Berkeley/ Los Angeles: University of California Press

. [1990] 2014. Bananas, beaches and bases: making feminist sense of international politics. Berkeley/Los Angeles: University of California Press

Galhera, Katiuscia Moreno and Tchella Maso. 2017. 'Abertura: Dossiê Feminismos, Gênero E Relações Internacionais.' Monções: Revista de Relações Internacionais da UFGD 6 (11): 1-14

Haraway, Donna. 1991. 'Situated Knowledges: the science question in feminism and the privilege of partial perspective.' In Donna Haraway (ed), Simians, Cyborgs and Women: The Reinvention of Nature. New York: Routledge, pp. 183-202

Inayatullah, Naeem and David Blaney. 2004. International Relations and the Problem of Difference. New York, London: Routledge.

Jones, Branwen Gruffydd (ed). 2006. Decolonizing International Relations. Lanham: Rowman \& Littleffield.

Lugones, María. 2010. 'Toward a decolonial feminism.' Hypatia 25 (4): 742-759.

Mignolo, Walter. 2000. Local Histories/Global Designs: Coloniality, Subaltern Knowledges, and Border Thinking. Princeton: Princeton University Press.

Mohanty, Chandra Talpade. 1984. 'Under Western Eyes: Feminist Scholarship and Colonial Discourses.' Boundary 12 (3) 13 (1): 333-358.

Tickner, Arlene and David Blaney (eds). 2013. Claiming the International: Worlding beyond the West. New York: Routledge.

Spivak, Gayatri C. 1988. 'Can the subaltern speak?' In Cary Nelson and Lawrence Grossbery (eds). Marxism and the Interpretation of Culture. Urbana: University of Illinois, pp. 271-313.

Walsh, Catherine. 2013. Pedagogías Decoloniales: Práticas insurgentes de resistir, (re)existiry (re)vivir. Quito: Ediciones Abya-Yala. 


\section{About the Author}

Natália Maria Félix de Souza is Professor at the International Relations Department of the Pontifical Catholic University of São Paulo (PUC-SP), and holds a PhD from IRI/ PUC-Rio, in which she engaged the limits of critique in international relations theory. Her work focuses mainly on critical approaches to subjectivity and subject formation, including feminist, post-structural, postcolonial and posthuman theories, and on decolonial approaches to knowledge and knowledge production. She is currently engaged in a number of initiatives regarding Gender, Sexuality and Women's Studies, including: co-editing the Conversations Section of the International Feminist Journal of Politics; co-editing a Portuguese-language book on 'Feminism, Gender and International Relations;' and advancing the agenda of MulheRIs in Brazilian IR.

Received on 5 September 2018, and approved for publication on 8 September 2018. 